\title{
To integrate or to segregate food crop and energy crop cultivation at the landscape scale? Perspectives on biodiversity conservation in agriculture in Europe
}

\author{
Jens Dauber ${ }^{1 *}$ and Saori Miyake ${ }^{2}$
}

\begin{abstract}
Biodiversity is severely declining in intensively managed agriculture worldwide. In response, land-management strategies for biodiversity conservation on farmland are in debate, namely ecological intensification and land sparing vs. land sharing. In parallel, there is a recent food vs. energy debate stimulated by an increasing competition for land resources. Despite clear overlaps between these two debates, they were rarely connected in previous research. This paper aims to stimulate a discussion by providing a contextual link between biodiversity conservation strategies and options for future energy crop deployment. Therefore, nine conceptual land-use scenarios are developed, and then, the potential biodiversity implications are discussed based on the findings from past and ongoing research. These scenarios include the integration and segregation of both food and energy crops on lands with a range of productivity and suitability for agricultural production. We assume that the clear segregation between food crops on productive land and energy crops on marginal land is less likely to be a solution of mitigating the problems related to the biodiversity decline, especially in the European agricultural landscape context. In contrast, the integration of food and energy crop production systems at the farm to landscape scale has greater potential for ecological intensification, although conflicts with traditional nature conservation targets may arise. We conclude that broadening the perspectives of biodiversity conservation in agriculture is crucial, and the inclusion of energy crop production into the recent debates on biodiversity conservation strategies is helpful.
\end{abstract}

Keywords: Bioenergy, Land sparing, Land sharing, Ecological intensification, Sustainable intensification, Combined food and energy systems, High nature value (HNV) farming

Abbreviations: CFE, Combined food and energy system; HNV, High nature value; iLUC, Indirect land-use change; LUC, Land-use change; SRC, Short-rotation coppice

\section{Introduction}

A decrease in available arable land per capita due to a rapid population growth [1], a growing number of animals in agriculture that need to be fed and actions for climate change mitigation and adaptation [2,3] are aggravating the competition for land resources. These demands will result in conversion of additional land to agricultural use and/or further agricultural intensification on existing

\footnotetext{
* Correspondence: jens.dauber@thuenen.de

'Thünen Institute of Biodiversity, Bundesallee 50, 38116 Braunschweig, Germany

Full list of author information is available at the end of the article
}

productive land $[4,5]$. In this context, the potential impacts of bioenergy production on food security have been highly controversial (e.g. recent food vs. energy debate). Bioenergy expansion has exerted significant land-use pressures, intensifying the competition for land, water and other natural resources with food production, which resulted in various concerns over environmental and social sustainability $[6,7]$. On the other hand, energy crop production can bring opportunities for increased agricultural production and productivity, rural development, agricultural diversification and climate change mitigation [8-10]. 
Past research on bioenergy expansion mainly focused on markets and feedstock distribution $[9,10]$ or bioenergy potentials and land availability on national and global scales (e.g. [11-13]). Accordingly, studies looking into the impacts of bioenergy production on biodiversity and/or ecosystem services were mainly undertaken from national or global perspectives (e.g. [14, 15]). A number of spatially explicit modelling studies have also emerged to evaluate the biodiversity responses from energy crop production at regional, national and pan-national scales, maize in particular [16-19], some of which considered land-use change scenarios involving energy crop cultivation on marginal land of high nature value $[20,21]$. In addition, many field-scale or empirical studies with a focus on a particular energy crop have been conducted to compare biodiversity impacts with those of row crops or grasslands [22-24]. However, a small but increasing number of studies have also tackled the biodiversity issues associated with energy crop production on a farm and landscape scale. These studies included the spatial and temporal aspects of bioenergy-driven land-use change and/or adaptations of the whole farming system (e.g. [25-30]).

The questions of where and to what extent energy crops should be cultivated in agricultural landscapes to maintain and/or enhance biodiversity and ecosystem service provision cannot be easily answered. There is a discrepancy between the findings of coarse-scale/modelling studies (mostly indicating negative impacts) and finescale field-based studies (mostly suggesting positive effects in comparison with traditional agricultural crops). The biodiversity effects of energy crop cultivation can also significantly differ from climatic regions and crop types [31] and specific regional circumstances, such as landscape pattern and structure [24, 32]. Therefore, farming system-based approaches are more relevant to answer this question. The potential impacts on local biodiversity from energy crop cultivation needs to be considered in the context of severe biodiversity decline on agricultural land $[33,34]$. Thus, we suggest linking the discussion on biodiversity impacts from energy crop production with those of agricultural land-management strategies for biodiversity conservation, namely ecological intensification [35] and the land-sparing vs. land-sharing debate [36]. Addressing both issues may be possible through the right selection of energy crop [6] and the optimal agricultural practices [37]. Therefore, we focus on the spatial-temporal scale of a farming or a production system because the solutions for food and energy security, biodiversity and ecosystem services must be considered altogether. To define the research scope for this paper, our scenarios and discussions only focus on direct land-use change, while we fully acknowledge the importance of challenges resulting from indirect land-use change (iLUC) [38]. The latter would have to be considered in a future discussion. The aim of this paper is to explore and stimulate a discussion about innovative agricultural production systems, which can meet multiple goals at the same time-production of food, fodder and biomass feedstock for energy and industry uses, biodiversity conservation and promotion of ecosystem services. In this paper, we describe nine conceptual land-use scenarios, which both segregate and integrate energy crop cultivation from/with food and fodder production systems on land having different levels of productivity. Potential impacts of those scenarios are discussed on the basis of yield-biodiversity relationships [39]. We also discuss opportunities and barriers for these scenarios in relation to the biodiversity outcomes based on the findings from past and ongoing studies. Finally, we suggest alternative scenarios that integrate food and bioenergy systems, involving first-generation energy crops (i.e. usable as food/ fodder or energy feedstock) and dedicated energy crops (i.e. only usable as energy feedstock), taking account of the productivity levels of the farmland.

\section{Land-use scenarios based on segregation or integration of food and energy crop cultivation at coarse spatial scales (regional to national)}

Integration or segregation, or in other terms "land sparing" or "land sharing", are two land-management strategies for biodiversity conservation worldwide. The debate originated from their efficiency in different ecosystems, landscapes and biogeographic regions [36, 40, 41]. These two strategies can be easily adapted to the question on where to cultivate energy crops (e.g. [42]) to avoid negative land-use change (LUC) effects, including the impacts on biodiversity and ecosystems. The concepts of land sparing and land sharing can be applied to any energy crop production system on a range of spatial scales (sensu [43]). There are two types of land-sparing approaches. The first approach restricts energy crop production to less productive, degraded, marginal or abandoned agricultural land to minimise the LUC effects including iLUC [40, 44-46]. The second approach cultivates energy crops on land that has been freed up for other purposes through (sustainable) agricultural intensification, resulting in higher yields per hectare (ha) $[47,48]$. In contrast, a land-sharing approach for bioenergy involves combining systems of food and energy production on a field or a set of fields (CFE). There are two possible systems: (i) both energy and food crops are included in the crop rotation cycles or (ii) energy crops are planted as structural elements in landscapes such as "energy hedgerows" in agroforestry systems (e.g. [26]). The integration of both crops can be implemented on both land of high- and low-productivity levels. Trials have found CFE to be considerably less resource demanding and more amenable to sustainable production than conventional food-cropping systems [49]. In the developed countries, 
CFE systems are also expected to improve overall ecosystem functions [50]. Land sharing of food and energy crops could thus be a means of supporting sustainable intensification of agriculture [51].

For a comparative discussion, we have sketched a diagram to visualise those alternatives of integrating or segregating food and energy cropping at coarse spatial scales (Fig. 1). To redefine the idea of restricting energy crop cultivation to less productive land, we have adopted some definitions by Shortall [46]. However, the definitions and characterizations of land productivity were currently highly ambiguous. We have therefore opted for a pragmatic classification into (i) high-grade productive agricultural land which is environmentally and economically suitable for all food crops and (ii) lower grade land which is economically marginal for food production (i.e. areas where cost-efficient production is not possible due to a combination of given conditions including low soil fertility, adverse climate, impediments to cultivation techniques, agriculture policies and macroeconomic and legal conditions). The "marginality" of the land is determined with respect to the particular economic opportunities offered by land-use choices [52]. Areas with extremely poor soils, harsh weather environments and severely degraded areas are classified into (iii) land unsuited for food production. Nevertheless, the notion of this land category still contains technical and economic assumptions that production of energy crops is possible and economically feasible. Owing to advanced plant-breeding and genetic modification technologies, future energy crops are likely to be more resilient, requiring fewer nutrients and water [46]. Our final land category of (iv) "natural" land includes all types of land which are reserved for nature conservation. Those areas must be completely excluded from any agricultural activities (Fig. 1), although the use of biomass waste and forest residues from such areas for energy purposes is possible (e.g. [53]). We are also aware that the classification of land categories can vary across countries and regions. For example, remnant natural land hardly exists in rural landscapes in Europe, which are mostly dominated by cultural landscapes. Thus, current European nature conservation policy has more of a focus on species-rich farmland, such as designated Natura2000 sites and high nature value (HNV) farmlands [54]. These areas are classified as economically marginal land in our classification, not into this "natural" land category. On the other hand, "rewilded" areas are included in the natural land category [55].

We have adopted a coarse yield-biodiversity relationship [40] to characterise the four land categories described above (Fig. 1). The level of biodiversity in the low-grade land unsuitable for food production may be much lower than assumed in Fig. 1, in particular where the unfavourable conditions result from soil degradation or contamination. For such areas, restoration or phytoremediation are important strategies. However, this is beyond the scope of the paper.

The "pre-bioenergy" scenario (Fig. 1) presents the distribution of dominant land cover for the three land categories. Food crops are mainly produced on the most productive agricultural land. Crop yields on that land are high, owing to high soil fertility, high external inputs and intensive production systems. Accordingly, levels of biodiversity on that land are very low (Fig. 1; [33]). As land becomes more marginal, crop yields decline, options for intensification of management become economically restricted and therefore production systems become less intensive. Permanent grassland is becoming the dominant cover on such land. In some regions with economically

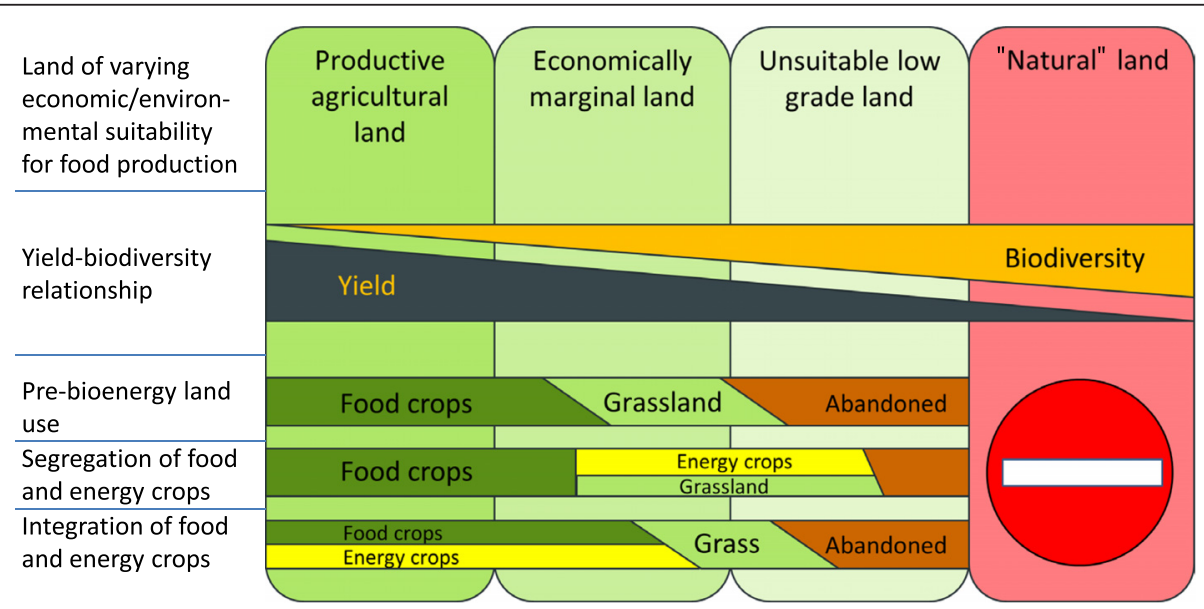

Fig. 1 Schematic of scenarios of segregating or integrating food and energy crop cultivation on land of different productivity and restrictions for agricultural development. The scenarios and their implications for the yield-biodiversity relationship are described in detail within the text 
marginal land, low-intensity farmland, sometimes with traditional farming practices, prevails [56]. Levels of farmland biodiversity on such land are high in comparison to those on productive agricultural land [54, 56]. On the low-grade land unsuitable for food production, high proportions of abandoned agricultural land occur due to mainly economic reasons, and high proportions of land not utilised for agriculture also occur due to environmental reasons. Extensive pastoral systems may exist on such land. Within the coarse yield-biodiversity relationship applied here, we expect to find high levels of biodiversity on such land. The highest levels of biodiversity are expected on "natural" land which is exempted from agricultural production (Fig. 1).

The "segregation of food and energy crops" scenario (Fig. 1) follows the "food-first" directive, postulating that food crops should be produced on the most productive land and energy crops should only be produced on land unsuitable for food production. In comparison to the "pre-bioenergy" scenario, this scenario involves conversion of only the most economically marginal lands (e.g. [57]), such as extensive agriculture, grazing, hay production and abandoned agricultural lands. Environmental impacts of restricting energy crops to these lands were discussed in our previous papers [45, 58]. From the perspective of biodiversity conservation in agriculture, this LUC may not result in positive biodiversity outcomes; thus, the scenarios should be carefully scrutinised. This is highly relevant to the European context. First, this scenario is unlikely to result in any improvement for biodiversity in the existing intensive farming areas, especially when the productive land is used for only food production and no steps are taken to support farmland biodiversity. Secondly, these types of land are generally characterised by comparatively high levels of farmland biodiversity, especially in Europe. Depending on the biodiversity values of the energy crops chosen, the biodiversity values of the land category converted and the functional integration (i.e. supplementing/complementing habitat functions) of the novel crops into the landscapes, the outcome may be positive, neutral or negative. Therefore, thorough regional impact assessments are necessary. Lastly, HNV farming systems in Europe which may exist in those lands are often threatened by non-sustainable socio-economic conditions [59]. The integration of energy crops can help to retain the HNV farming system and the associated species depending on the extensive and low-impact agricultural lands. The diversification also results in the opportunity to increase farmers' income and a stabilisation of the rural communities without harming the ecological component of those socio-ecological systems (sensu [59]). Permanent grassland with extensive grazing is an important type of land use on economically marginal land and land unsuitable for food production.
The "integration of food and energy crops" scenario (Fig. 1) combines the ideas that (i) a diversification of food production systems through energy crops does not undermine food security [50] and (ii) sufficient and sustainable cultivation of energy crops on marginal land is not achievable because of low yields, low feedstock quality, higher land take and the associated environmental and social issues [45]. In comparison to the segregation scenario, LUC occurs predominantly on the productive agricultural land and also on the economically marginal land. In the latter case, the boundaries of economic marginality shift due to a presumably higher profitability of combined food and energy systems in comparison to food production only. Due to the higher yields on the productive land, land unsuitable for food production is less affected by the expansion of energy crop production. A possible biodiversity outcome of this scenario depends on how the integration is undertaken. Hence, more detailed scenarios of the respective options at the farm to landscape scale are presented and discussed in the following section. In general, this scenario has the potential to halt or even reverse the biodiversity loss from intensive agriculture-if sustainable intensification is understood as ecological intensification [35]. For instance, a strategic integration of perennial crops is suggested as a means for the restoration of agroecosystems [60]. However, the benefit of such changes may mostly affect functional components of biodiversity and more common species as ecosystem service providers and not so much affect species of nature conservation concern. For the permanent grassland in the economically marginal land class affected in this scenario, considerations similar to the ones made for the segregation scenario would apply. In this context, integration of dedicated energy crops-mostly woody perennial crops, such as a variety of eucalypts-into extensive grazing have been also suggested in Australia to remedy natural resource management problems (e.g. salinity, biodiversity loss, water quality degradation), to increase farmers' profits through product diversification [61] and to explore carbon-offset opportunities [62].

\section{Scenarios of integrating energy crop and food crop cultivation at the farm to landscape scale}

To reconcile agricultural yields for food and/or energy crops and conservation of farmland biodiversity at the landscape level, choosing between pure land-sharing or land-sparing strategies may lead to suboptimal outcomes in many cases. This is because "optimal" landscapes will likely have features of both strategies [63]. Moreover, there is a wide variation in definitions of what constitutes the spared land, ranging from natural habitats, grazed grasslands to field boundaries [43]. Likewise, there is a range of ideas about the spatial scale at which land sparing is applicable [40, 64]. Ekroos et al. [43] 
suggested a multiple-scale land-sparing approach where the respective scale at which land-sparing options were applied corresponds to the most appropriate aspects of biodiversity conservation.

For our scenarios, the sparing of habitats within landscape mosaics is of relevance. Many common species including ecosystem service providers (e.g. biocontrol agents and pollinators) move tens to thousands of metres during a day or season to use multiple habitats that offer complementary or supplementary resources $[65,66]$. To this effect, a field of a low-input dedicated energy crops may function as a "spared" habitat in providing resources to farmland species, comparable to a spared semi-natural habitat. Accordingly, including an energy crop into a crop rotation cycle or in doublecropping systems may function as a sharing type of measure for supporting biodiversity.

Looking at the options for segregating or integrating food and energy crops at the farm to landscape scale (i.e. a spatial cluster of farms), pure energy farms would represent a pure sparing solution and combined food and energy farms a sharing solution. In reality, farms specialising only on the production of energy crops are uncommon in an agricultural context. Therefore, we focus our scenario development for the integration of both food and energy crop production. Such integration could be achieved by converting both productive and economically marginal agricultural lands, albeit in each case different energy crops are involved, including either intensive crops (i.e. first-generation energy crops) or dedicated energy crops (e.g. grass and woody perennial crops), which are often less intensive in management [67]. For the latter, cultivation on land unsuitable for food production may also be viable. We therefore include scenarios with first-generation energy crops only (A1, B1; Fig. 2), spatio-temporal combinations of firstgeneration energy crops and dedicated energy crops (A2, B2; Fig. 2) and dedicated energy crops only (perennial crops, A3, B3, C1-3; Fig. 2). The options for an integration of food and energy crops therefore differ in the spatial and temporal combinations of the respective crops, in particular. Use of waste materials, slurry or manure for bioenergy is not explicitly taken into account here but might be an integral part of the respective bioenergy chains.

The scenarios presented in Fig. 2 are not exhaustive, and several more options for integrating food and energy crops may exist. The detailed description of nine scenarios with a range of production intensities and systems (A1C3) enables us to identify the risks and the opportunities associated with biodiversity conservation within the respective scenarios. Possible impacts of land-use change induced by energy crop integration across scenarios are not taken into consideration. All scenarios (Fig. 2) were realised in a farming context or at least tested in

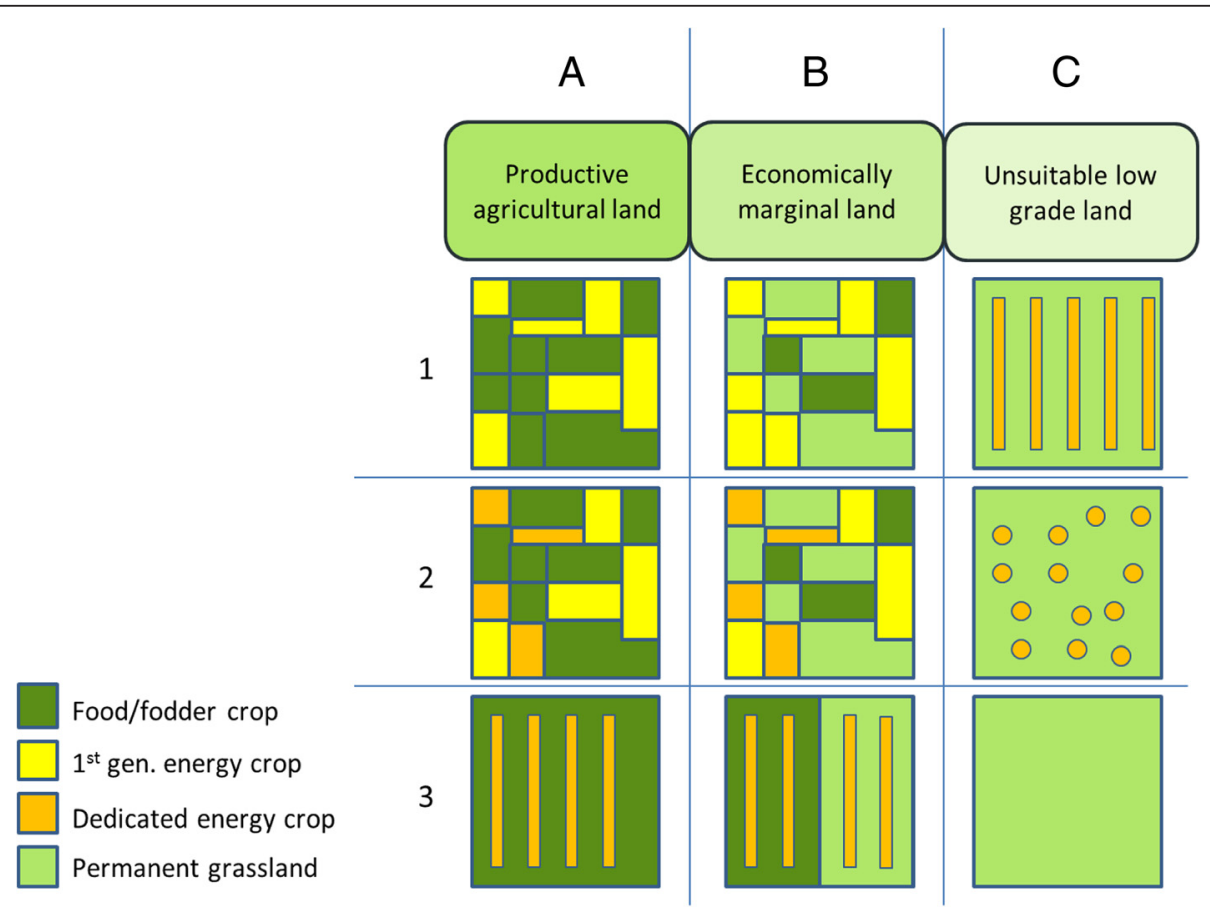

Fig. 2 Scenarios of integrating energy crop cultivation in open land varying in suitability for food production. The scenarios focus on coarse categories of land use including food/fodder crops, so-called first-generation energy crops, dedicated energy crops and permanent grassland. For each land type $(A-C)$, three separate scenarios were developed in which the intensity of land management decreases from 1 to 3 . The scenarios are described in detail within the text 
experimental setups. Their characteristics are presented below together with examples of their implementations.

\section{A1: First-generation energy crop production on productive agricultural land}

The energy crops combined with food/fodder crops in this scenario are annual first-generation crops (e.g. oilseed rape, maize) for the production of bioethanol, biodiesel or biogas. The crops can be cultivated in rotation with food crops or in inter- or double-cropping systems. In the case of maize, they can also be grown as monocultures. Oilseed rape and maize cover high proportions of the utilised agricultural area (UAA) in some areas of Europe and North America (e.g. [68]). Those systems do not differ from conventional food cropping in terms of management intensity and levels of inputs (e.g. plant protection and fertilisation). Therefore, such systems do not improve the conditions for farmland biodiversity but could rather aggravate the situation with covering a high proportion of the UAA [17]. Oilseed rape, as a mass flowering crop, can provide food resources for pollinating insects but only during a limited period of the year [69]. A sustainable benefit for pollinators can only be achieved when a continuous flower supply is ensured through supplementary habitats in the landscape [29].

\section{A2: Combination of first-generation and dedicated energy} crops on productive agricultural land

This scenario presents a less intensive, lower input and more diversified version of scenario A1. Here, annual first-generation crops are combined with fields, or field strips, of dedicated (annual or perennial) biomass crops planted in the vicinity of food/fodder crops. Such cropping systems are sometimes tested as more sustainable and biodiversity-friendly alternatives to A1. Examples are an inclusion of switchgrass or mixed-grass-forb prairie in maize production [24], strips of wildflower mixtures for biogas in maize-dominated areas [70] and alternative crops to maize, such as the cup plant Silphium perfoliatum L. [71]. Including dedicated energy crops, perennial crops in particular, in intensive foodcropping systems could mitigate some of the pressures on farmland biodiversity by lowering input levels, lowering the speed of production cycles, increasing crop diversity, regenerating soils and providing continuous resources for ecosystem service providers [24, 50, 72, 73].

\section{A3: Strips of dedicated energy crops on productive agricultural land}

Strips of dedicated energy crops planted as alleys in extensive fields of food crops could serve diverse purposes. Silvo-arable agroforestry systems with fast growing trees for short-rotation coppice (SRC) can function as wind breaks, stopping wind erosion of soil in plains [74]. Perennial buffer strips adjacent to annual crops can reduce soil sediment and nutrient inputs into surface waters, increase carbon storage, improve farmland biodiversity and reduce pesticide drift into natural habitats $[60,74]$. Agroforestry systems established on agricultural land were shown to mitigate many of the negative impacts of agriculture, for supporting biodiversity and enhancing natural regulation of pests $[75,76]$. Evidence for such multi-functional effects from agroforestry dedicated to bioenergy is, however, still scarce [74]. An alternative to SRC strips could be strips of herbaceous crops or flower mixtures. Positive impacts of such strips on pollinating insects and natural pest control were shown for mixtures developed for nature conservation in agricultural landscapes [77, 78]. Evidence of comparable benefits from wildflower strips designed specifically for energy purposes has yet to be established.

\section{B1: First-generation energy crop production on economically marginal land}

This scenario resembles A1 but on lower grade soils and/or under stronger climatic limitations to crop cultivation. Different crop varieties or species may be grown in comparison to A1 [79]. In drought-prone environments, for example, sweet sorghum and sorghum-sudangrass hybrids were tested as alternatives to maize for biogas production in Germany [80]. Like in A1, the combined systems do not differ from pure food/fodder systems in their farming intensity and hence are most likely to have negative effects on biodiversity. When bioenergy feedstock production becomes more economically profitable than fodder production or grazing on permanent grassland, the latter is likely to be converted into fields of energy crops. Problems for nature conservation connected to such conversion of permanent grassland, together with management changes, such as shorter crop rotation cycles and earlier harvesting times, were reported from Germany [81]. Here, the amendment of the Renewable Energy Act in 2004 together with the implementation of a bonus payment for the production of electricity from renewable raw materials led to maize becoming the predominate energy crop for biogas production, resulting in the aforementioned land-management changes.

\section{B2: Combination of first-generation and dedicated energy} crops on economically marginal land

Dedicated energy crops, in particular perennial lignocellulosic crops, are often suggested for cultivation on lower grade soils [82, 83]. Miscanthus and other energy grasses together with SRC plantations of fast growing trees, such as willow and poplar, are among the prime candidate crops in Europe. Their field-scale impacts on biodiversity are often deemed positive in comparison to 
conventional food crops [23]. As discussed in A2, they could mitigate some of the pressures on farmland biodiversity. The potential impacts of such combined food and energy systems on economically marginal land, however, need to be discussed against the issues of marginal yields from those lands together with the questions of how they can interact with HNV farming systems and nature conservation priorities (see [45] for a more detailed discussion of those issues). In this context, a good strategic planning and landscape design for bioenergy may provide an opportunity to move forward more sustainable production systems [84]. For example, Ruskule et al. [85] showed that the spatial pattern of afforestation on abandoned agricultural land had an impact on the respective biodiversity outcome in Latvia. More importantly, energy crop production from marginal lands could directly compete with forage-livestock production. A conversion of forage production, including switchgrass, reed canary grass and alfalfa, to energy farming could push the traditional forage-livestock industry to even more marginal lands [86] (Fig. 1). In Ireland, where production of grass as fodder has a long tradition, conversion of grass biomass from fodder to biogas production was suggested due to the high energy yields. Biomethane from grass had a very good energy balance; thus, the conversion was expected to involve less habitat destruction, LUC, new farming practices or annual tilling [87]. Nevertheless, those grasslands are intensively managed, receiving high fertiliser application rates and frequent mowing, which can result in degraded species pools and structurally homogenous swards $[88,89]$. Therefore, the biodiversity outcomes of this scenario remain largely unknown. Along with the production of dedicated crops, the use of successional vegetation as bioenergy feedstock was also suggested as a productive alternative despite the soil and climate restrictions typically found in marginal lands [90]. This alternative may be relevant for abandoned agricultural land in this scenario but also has implications for scenario C3 on land unsuitable for food production.

\section{B3: Strips of dedicated energy crops on economically marginal land}

In comparison to $\mathrm{B} 2$, the focus of this scenario is on the introduction of woody perennial crops integrated as agroforestry systems into existing annual or perennial land use. An example for this is the cultivation of southern mallee eucalypts in the extensive dryland wheat and sheep regions of southern Australia where they were introduced to remedy a range of natural resource management problems [61]. Glemnitz et al. [91] found that SRC strips in a region of north-east Germany exhibited unique habitat conditions that distinguished their biotic communities from those of all other habitats within the agricultural landscape. However, they concluded that the SRC strips contributed little to traditional nature conservation targets, such as rare species, but that they improved habitat connectivity and ecosystem services [91]. In consequence, a conflict may arise between biodiversity conservation targets (i.e. conservation of rare species and habitats [fine scale] and conservation of biodiversity-friendly farming systems [coarse scale]), for bioenergy development in such marginal areas when they are of high nature conservation value. Environmental potentials of agroforestry have been discussed in A3 and mostly apply to this land type as well.

\section{C1 and 2: Woody perennial crops on low-grade land}

These scenarios developed for land type $C$ do not describe an integration of energy and food cropping systems in a strict sense because by definition lands of type $\mathrm{C}$ were characterised as unsuitable for food production. Nevertheless, extensive pastoral systems may exist on this type of land. Silvo-pastoral agroforestry, in comparison to ranching systems without shrubs or trees, is known to provide habitat structures and resources and that support and enhance biodiversity and maintain vital ecological processes in pastoral landscapes [92, 93]. In addition, the inclusion of trees within cultivated landscapes delivers a range of social-ecological benefits [51]. In comparison to timber and fruit as tree products from those systems, the option as feedstock for bioenergy appears to be less developed.

\section{C3: Biomass from (semi-)natural vegetation}

In this scenario, the vegetation biomass from permanent grasslands is directly used for energy purposes [90]. Biodiversity impacts of this utilisation are largely unknown but will depend on whether changes in grassland management would be involved [81].

\section{Discussion of potential impacts of the application of suggested scenarios based on current studies}

By comparing scenarios of segregated and integrated food and energy cropping at coarse spatial scales with yield-biodiversity relationships across land productivity classes (Fig. 1), we could explore possible risks and opportunities for biodiversity conservation across different bioenergy deployment strategies. We reasoned that a strict segregation of food and energy crops with a restriction of energy crop cultivation on economically marginal land and land unsuitable for food crop production is unlikely to mitigate the current situation of biodiversity loss originating from intensive agricultural systems on productive land, especially in the European context. If no alternative measures for biodiversity conservation were developed within intensive agriculture, we would share the concern of Ekroos et al. [43], who argued that segregation strategies could increase the existing negative effects 
on biodiversity, and even erode ecosystem services that could underpin sustainable, high-yielding farming systems based on ecological intensification [35]. Our analysis demonstrated that most of the LUC in the sparing strategy would occur within the economically marginal land category. Further regional/local investigations are certainly required to establish whether energy crops on this type of land would (i) replace HNV farmland and/or habitats of nature conservation value [20], potentially resulting in habitat loss and biodiversity decline, and (ii) sustain economically threatened socio-ecological HNV farming systems [59] and thereby support conservation. Strohbach et al. [54] suggested that if the social component underlying a HNV farming system has ceased to exist or is not sustainable anymore, new HNV farming systems based on different techniques and diversification of farm income would have to be developed. Integration of energy crops into those farming systems may be one possible "transformation strategy" (sensu [59]). However, an introduction of novel crops will most likely alter farmland species communities and may conflict with existing nature conservation targets.

The scenario of integrating food and energy crops at a coarse scale (Fig. 1) resulted in LUC on productive land. Integration of energy crops into intensive and industrialised production systems may facilitate transformation towards agroecological cropping practices [94] and support sustainable intensification [50]. More evidence is required to answer questions over whether such integration will (i) increase the provision of ecosystem services relevant for agriculture, (ii) promote endangered farmland species and (iii) facilitate migration of non-farmland species through the agricultural matrix. Those functions were so far only connected to semi-natural habitats [41]. Exemplary studies have already given evidence that the integration strategy could work (e.g. [24, 41, 72, 73, 91]). Nevertheless, many open questions remain to be investigated that include the amount of land that needs to be converted to energy crops and the landscape conditions under which ecosystem service provisions vary over time and interactions between different sustainable intensification strategies [43].

Our conceptual scenarios of various production intensities and production systems (Fig. 2) have facilitated a detailed evaluation of bioenergy deployment strategies with respect to practical implementation and ecological effects. A comparison of the respective scenarios indicated that a combination of food and energy cropping either on productive or marginal land does not always lead to positive outcomes for biodiversity and ecosystem services (Table 1). On the contrary, A1 and B1 scenarios indicated that such integration could result in accelerating existing threats by reduction of crop diversity and length of crop rotations and by increase in agrochemical inputs. Alternatively, scenarios A2, A3, B2 and B3 highlighted that the integration of dedicated energy crops, perennials in particular, could support ecological intensification of farming systems alongside the delivery of biodiversity conservation. However, the components of (farmland) biodiversity benefitting from those developments may not be identical with traditional nature conservation targets. In this context, reconsideration, reformulation and regional adaptation of biodiversity goals and measures may be helpful for specific farming systems to resolve the conflicts. However, realising integrated strategies in practice is complicated due to various environmental, economic and political obstacles and economic situation and attitudes of farmers towards these new production ideas. Diverse land-management

Table 1 Expected risks and opportunities for biodiversity conservation from suggested scenarios

\begin{tabular}{|c|c|c|c|}
\hline Scenarios & Energy crop types & Production system? & Risks and opportunities for biodiversity conservation \\
\hline A1 & 1st-gen. crops & \multirow{3}{*}{$\begin{array}{l}\text { Productive agricultural land } \\
\text { (food/fodder crops) }\end{array}$} & Risk of no improvements in farmland biodiversity \\
\hline A2 & $\begin{array}{l}\text { 1st-gen. crops + dedicated } \\
\text { energy crops }\end{array}$ & & $\begin{array}{l}\text { Opportunity for mitigating pressures on farmland } \\
\text { biodiversity }\end{array}$ \\
\hline A3 & Dedicated energy crops & & $\begin{array}{l}\text { Opportunities for mitigating various impacts of } \\
\text { agriculture and supporting biodiversity }\end{array}$ \\
\hline B1 & 1st-gen. crops & \multirow{3}{*}{$\begin{array}{l}\text { Economically marginal land } \\
\text { (food/fodder crops and } \\
\text { permanent grassland) }\end{array}$} & Risks of negative effects on grassland biodiversity \\
\hline B2 & $\begin{array}{l}\text { 1st-gen. crops + dedicated } \\
\text { energy crops }\end{array}$ & & $\begin{array}{l}\text { Risks and opportunities depending on a planning and } \\
\text { landscape design; opportunity for stabilising HNV } \\
\text { farming systems }\end{array}$ \\
\hline B3 & Dedicated energy crops & & $\begin{array}{l}\text { Trade-off between conservation of rare species and } \\
\text { habitats and conservation of biodiversity-friendly } \\
\text { farming systems }\end{array}$ \\
\hline $\mathrm{C} 1 ; \mathrm{C} 2$ & Dedicated energy crops & $\begin{array}{l}\text { Unsuitable low-grade land } \\
\text { (semi-natural vegetation, } \\
\text { permanent grassland) }\end{array}$ & $\begin{array}{l}\text { Opportunity for supporting and enhancing biodiversity } \\
\text { through supporting pastoral systems }\end{array}$ \\
\hline C3 & $\begin{array}{l}\text { Vegetation biomass from } \\
\text { grasslands }\end{array}$ & & Unknown, depending on changes in management \\
\hline
\end{tabular}


options will require the engagement of a wide array of stakeholders in decision-making to address multiple objectives and trade-offs between ecosystem, social, and economic services [84]. In this regard, the education for farmers is essential in relation to sustainable integration of energy crops into the existing agricultural production system. This may be followed by engagement of the farmers/land owners in decision-making on land-use policy and spatial planning for the region. The complexity of the topic may also require a strategic, spatially explicit landscape planning or landscape design [84]. This in turn would often require a strengthening of planning systems, of legal instruments, the implementation of certification schemes or the refinement of existing subsidy systems [95]. When thinking towards such landscape-design approaches, the administrative burdens associated with them should not be out of proportion to the achievable benefits.

The development of scenarios on integrated and segregated food and energy cropping was intended to stimulate and broaden the discussion on the development of more sustainable, especially more biodiversity-friendly, farming systems that contribute to energy as well as food security, within the context of current debates on land sparing and sharing, and ecological intensification. We argue that energy crop production (as well as other industrial crops) should not be rationalised away from the food security debate especially in Europe where land resource is highly limited. Thus, further evaluations are required for both land-sparing and land-sharing scenarios. We propose that it is important to consider how the wide range of energy crops, with their specific traits and management requirements, may play a role when devising novel and more sustainable agricultural production systems. Such integration may result in either positive or negative outcomes, depending on how well it is designed.

\section{Acknowledgements}

We thank David Styles for his valuable comments and suggestions on the manuscript.

\section{Funding}

SM is funded by the DAAD (German Academic Exchange Service).

\section{Authors' contributions}

Both authors contributed to the text of the paper, and JD developed the scenarios. Both authors read and approved the final manuscript.

\section{Competing interests}

The authors declare that they have no competing interests.

\section{Author details}

Thünen Institute of Biodiversity, Bundesallee 50, 38116 Braunschweig, Germany. ${ }^{2}$ IWAR, Chair of Material Flow Management and Resource Economy, Technischen Universität Darmstadt, Franziska-Braun-Straße 7, 64287 Darmstadt, Germany.

Received: 7 May 2016 Accepted: 16 August 2016 Published online: 13 September 2016

\section{References}

1. FAO (2009) Global agriculture towards 2050. High-level expert forum, Rome, 12-13 Oct. 2009: 1-4. http://www.fao.org/fileadmin/templates/wsfs/docs/ Issues_papers/HLEF2050_Global_Agriculture.pdf. Accessed 2 Aug 2016

2. OECD-FAO (2009) Agricultural outlook 2009-2018-Highlights. OECD/FAO: 1-95. http://www.oecd.org/berlin/43042301.pdf. Accessed 2 Aug 2016

3. Tirado MC, Cohen MJ, Aberman N, Meerman J, Thompson B (2010) Addressing the challenges of climate change and biofuel production for food and nutrition security. Food Res Int 43:1729-1744

4. Spiertz JHJ, Ewert F (2009) Crop production and resource use to meet the growing demand for food, feed and fuel: opportunities and constraints. NJAS - Wageningen J Life Sci 56:281-300

5. Popp J, Lakner Z, Harangi-Rákos M, Fári M (2014) The effect of bioenergy expansion: food, energy, and environment. Renew Sust Energ Rev 32:559-578

6. Dornburg V, van Vuuren $D$, van de Ven $G$, Langeveld $H$, Meeusen M, Banse M, van Oorschot M, Ros J, van den Born GJ, Aiking H, Londo M, Mozaffarian H, Verweij P, Lyseng E, Faaij A (2010) Bioenergy revisited: Key factors in global potentials of bioenergy. Energy Environ Sci 3:258-267

7. Miyake S, Renouf M, Peterson A, McAlpine C, Smith C (2012) Land-use and environmental pressures resulting from current and future bioenergy crop expansion: a review. J Rural Stud 28:650-658

8. Ewing M, Msangi S (2009) Biofuels production in developing countries: assessing tradeoffs in welfare and food security. Environ Sci Policy 12:520-528

9. Nonhebel S (2012) Global food supply and the impacts of increased use of biofuels. Energy 37:115-121

10. Maltsoglou I, Kojakovic A, Rincon LE, Felix E, Branca G, Valle S, Gianvenuti A, Rossi A, Thulstrup A, Thofern H (2015) Combining bioenergy and food security: An approach and rapid appraisal to guide bioenergy policy formulation. Biomass Bioenerg 79:80-95

11. Johansson K, Liljequist K, Ohlander L, Aleklett K (2010) Agriculture as provider of both food and fuel. AMBIO 39:91-99

12. Beringer $T$, Lucht $W$, Schaphoff S (2011) Bioenergy production potential of global biomass plantations under environmental and agricultural constraints. Glob Change Biol Bioenergy 3:299-312

13. Valentine J, Clifton-Brown J, Hastings A, Robson P, Allison G, Smith P (2012) Food vs. fuel: the use of land for lignocellulosic 'next generation' energy crops that minimize competition with primary food production. Glob Change Biol Bioenergy 4:1-19

14. Koh LP, Ghazoul J (2008) Biofuels, biodiversity, and people: understanding the conflicts and finding opportunities. Biol Cons 141:2450-2460

15. Holland RA, Eigenbrod F, Muggeridge A, Brown G, Clarke D, Taylor G (2015) A synthesis of the ecosystem services impact of second generation bioenergy crop production. Renew Sust Energ Rev 46:30-40

16. Fletcher RJ Jr, Robertson BA, Evans L, Doran PJ, Alavalapati JRR, Schemske DW (2011) Biodiversity conservation in the era of biofuels, risks and opportunities. Front Ecol Environ 3:161-168

17. Gevers J, Hoye TT, Topping CJ, Glemnitz M, Schroeder B (2011) Biodiversity and the mitigation of climate change through bioenergy, impacts of increased maize cultivation on farmland wildlife. Glob Change Biol Bioenergy 3:472-482

18. Everaars J, Frank K, Huth A (2014) Species ecology and the impacts of bioenergy crops: an assessment approach with four example farmland bird species. Glob Change Biol Bioenergy 6:252-264

19. Sauerbrei R, Ekschmitt K, Wolters V, Gottschalk TK (2014) Increased energy maize production reduces farmland bird diversity. Glob Change Biol Bioenergy 6:265-274

20. Hellmann F, Verburg PH (2010) Impact assessment of the European biofuel directive on land use and biodiversity. J Environ Manage 91:1389-1396

21. Hellmann F, Verburg PH (2011) Spatially explicit modelling of biofuel crops in Europe. Biomass Bioenerg 35:2411-2424

22. Baum S, Weih M, Busch G, Kroiher F, Bolte A (2009) The impact of short rotation coppice plantations on phytodiversity. Landbauforschung - vTI Agri Forest Res 59:163-170

23. Dauber J, Jones M, Stout J (2010) The impact of biomass crop cultivation on temperate biodiversity. Glob Change Biol Bioenergy 2:289-309

24. Werling BP, Meehan TD, Gratton C, Landis DA (2011) Influence of habitat and landscape perenniality on insect natural enemies in three candidate biofuel crops. Biol Control 59:304-312

25. Koh LP, Levang P, Ghazoul J (2009) Designer landscapes for sustainable biofuels. Trend Ecol Evol 24:431-438 
26. Porter J, Costanza R, Sandhu H, Sigsgaard L, Wratten S (2009) The value of producing food, energy, and ecosystem services within an agro-ecosystem. AMBIO 38:186-193

27. Harvolk S, Kornatz P, Otte A, Simmering D (2014) Using existing landscape data to assess the ecological potential of Miscanthus cultivation in a marginal landscape. Glob Change Biol Bioenergy 6:227-241

28. Brandt K, Glemnitz M (2014) Assessing the regional impacts of increased energy maize cultivation on farmland birds. Environ Monit Assess 186:679-697

29. Diekötter T, Peter F, Jauker B, Wolters V, Jauker F (2014) Mass-flowering crops increase richness of cavity-nesting bees and wasps in modern agro-ecosystems. Glob Change Biol Bioenergy 6:219-226

30. Styles D, Gibbons J, Williams AP, Dauber J, Stichnothe H, Urban B, Chadwick DR, Jones DL (2015) Consequential life cycle assessment of biogas, biofuel and biomass energy options within an arable crop rotation. Glob Change Biol Bioenergy 7:1305-1320

31. Immerzeel DJ, Verweij PA, van der Hilst F, Faaij APC (2014) Biodiversity impacts of bioenergy crop production: a state-of-the-art review. Glob Change Biol Bioenergy 6:183-209

32. Pedroli B, Elbersen B, Frederiksen P, Grandin U, Heikkilä R, Krogh PH, Izakovičová Z, Johansen A, Meiresonne L, Spijker J (2013) Is energy cropping in Europe compatible with biodiversity? Opportunities and threats to biodiversity from land-based production of biomass for bioenergy purposes. Biomass Bioenerg 55:73-86

33. Henle K, Alard D, Clitherow J, Cobb P, Firbank L, Kull T, McCracken D, Moritz RFA, Niemelä J, Rebane M, Wascher D, Watt A, Young J (2008) Identifying and managing the conflicts between agriculture and biodiversity conservation in Europe-a review. Agric Ecosyst Environ 124:60-71

34. Cunningham SA, Attwood SJ, Bawa KS, Benton TG, Broadhurst LM, Didham RK, McIntyre S, Perfecto I, Samways MJ, Tscharntke T, Vandermeer J, Villard M-A, Young AG, Lindenmayer DB (2013) To close the yield-gap while saving biodiversity will require multiple locally relevant strategies. Agric Ecosyst Environ 173:20-27

35. Bommarco R, Kleijn D, Potts SG (2013) Ecological intensification: harnessing ecosystem services for food security. Trends Ecol Evol 28:230-238

36. Fischer J, Abson DJ, Butsic V, Chappell MJ, Ekroos J, Hanspach J, Kuemmerle T, Smith HG, von Wehrden H (2014) Land sparing versus land sharing: moving forward. Conserv Lett 7:149-157

37. Chappell MJ, LaValle LA (2011) Food security and biodiversity: can we have both? An agroecological analysis. Agric Hum Values 28:3-26

38. Searchinger T, Heimlich R, Houghton RA, Dong FX, Elobeid A, Fabiosa J, Tokgoz S, Hayes D, Yu TH (2008) Use of U.S. croplands for biofuels increases greenhouse gases through emissions from land use change. Science 319:1238-1240

39. German RN, Thompson CE, Benton TG (2016) Relationships among multiple aspects of agriculture's environmental impact and productivity: a metaanalysis to guide sustainable agriculture. Biol Rev. doi:10.1111/brv.12251

40. Phalan B, Balmford A, Green RE, Scharlemann JPW (2011) Minimising the harm to biodiversity of producing more food globally. Food Policy 36:S62-S71

41. Herzog F, Schüepp C (2013) Are land sparing and land sharing real alternatives for European agricultural landscapes? Aspect Appl Biol 121:109-116

42. Anderson-Teixera KJ, Duval B, Long SP, DeLucia EH (2012) Biofuels on the landscape: is "land sharing" preferable to "land sparing"? Ecol Appl 22:2035-2048

43. Ekroos J, Ödman AM, Andersson GKS, Birkhofer K, Herbertsson L, Klatt BK, Olsson O, Olsson PA, Persson AS, Prentice HC, Rundlöf M, Smith HG (2016) Sparing land for biodiversity at multiple spatial scales. Front Ecol Evol 3:145. doi:10.3389/fevo.2015.00145

44. Campbell JE, Lobell DB, Genova RC, Field CB (2008) The global potential of bioenergy on abandoned agriculture lands. Environ Sci Technol 42:5791-5794

45. Dauber J, Brown C, Fernando AL, Finnan J, Krasuska E, Ponitka J, Styles D, Thrän D, Van Groenigen KJ, Weih M, Zah R (2012) Bioenergy from "surplus" land, environmental and socio-economic implications. BioRisk 7:5-50

46. Shortall OK (2013) "Marginal land" for energy crops: exploring definitions and embedded assumptions. Energy Policy 6:19-27

47. Faaij A (2007) Biomass resource potentials; where are they? In: Haverkort A, Bindraban P, Bos H (eds) Food, fuel or forest? Opportunities, threats and knowledge gaps of feedstock production for bio-energy. Plant Research International B.V., report 142, Wageningen, pp 13-19

48. Strassburg BBN, Latawiec AE, Barioni LG, Nobre CA, da Silva VP, Valentim JF, Vianna M, Assad ED (2014) When enough should be enough: improving the use of current agricultural lands could meet production demands and spare natural habitats in Brazil. Global Environ Chang 28:84-97

49. Ghaley BB, Porter JR (2013) Emergy synthesis of a combined food and energy production system compared to a conventional wheat (Triticum aestivum) production system. Ecol Ind 24:534-542

50. Heaton EA, Schulte LA, Berti M, Langeveld H, Zegada-Lizarazu W, Parrish D, Monti A (2013) Managing a second-generation crop portfolio through sustainable intensification: examples from the USA and the EU. Biofuels Bioprod Bioref 7:702-714

51. Pretty J, Bharucha ZP (2014) Sustainable intensification in agricultural systems. Ann Bot-London 114:1571-1596

52. Nalepa RA, Bauer DM (2012) Marginal lands: the role of remote sensing in constructing landscapes for agrofuel development. J Peasant Stud 39:403-422

53. Müller G, Holderegger R, Bürgi M (2016) Energie aus Landschaftspflegegrün. WSL Berichte 38:1-56

54. Strohbach MW, Kohler ML, Dauber J, Klimek S (2015) High nature value farming: from indication to conservation. Ecol Ind 57:557-563

55. Navarro LM, Pereira HM (2012) Rewilding abandoned landscapes in Europe. Ecosystems 15:900-912

56. Sutcliffe LME, Batáry P, Kormann U, Báldi A, Dicks LV, Herzon I, Kleijn D, Tryjanowski P, Apostolova I, Arlettaz R, Aunins A, Aviron S, Balezentiene L, Fischer C, Halada L, Hartel T, Helm A, Hristov I, Jelaska SD, Klimek S, Koorberg P, Kostiukov J, Kovacs-Hostyanszki A, Kuemmerle T, Leuschner C Lindborg R, Loos J, Maccherini S, Marja R, Mathe O, Paulini I, Proenca V, Rey-Benayas J, Xavier Sans F, Seifert C, Stalenga J, Timaeus J, Torok P, van Swaay C, Viik E, Tscharntke T (2015) Harnessing the biodiversity value of Central and Eastern European farmland. Diversity Distrib 21:722-730

57. Borland AM, Griffiths H, Hartwell J, Smith JAC (2009) Exploiting the potential of plants with crassulacean acid metabolism for bioenergy production on marginal lands. J Exp Bot 60:2879-2896

58. Miyake S, Smith C, Peterson A, McAlpine C, Renouf M, Waters D (2015) Environmental implications of using 'underutilised agricultural land' for future bioenergy crop production. Agri Syst 139:180-195

59. Fischer J, Hartel T, Kuemmerle T (2012) Conservation policy in traditional farming landscapes. Conserv Lett 5:167-175

60. Schulte LA, Liebman M, Asbjornsen H, Crow TR (2006) Agroecosystem restoration through strategic integration of perennials. J Soil Water Cons 61:164A-169A

61. Shepherd M, Bartle J, Lee DJ, Brawner J, Bush D, Turnbull P, Macdonell P, Brown TR, Simmons B, Henry R (2011) Eucalypts as a biofuel feedstock. Biofuels 2:639-657

62. Farine DR, O'Connell DA, Raison RJ, May BM, O'Connor MH, Crawford DF, Herr A, Taylor JA, Jovanovic T, Campbell PK, Dunlop MIA, Rodriguez LC, Poole ML, Braid AL, Kriticos D (2012) An assessment of biomass for bioelectricity and biofuel, and for greenhouse gas emission reduction in Australia. Glob Change Biol Bioenergy 4:148-175

63. Butsic V, Kuemmerle T (2015) Using optimization methods to align food production and biodiversity conservation beyond land sharing and land sparing. Ecol Appl 25:589-595

64. Gabriel D, Sait SM, Kunin WE, Benton TG (2013) Food production vs. biodiversity: comparing organic and conventional agriculture. J Appl Ecol 50:355-364

65. Dunning JB, Danielson BJ, Pulliam RH (1992) Ecological processes that affect populations in complex landscapes. Oikos 65:169-175

66. Fahrig L, Baudry J, Brotons L, Burel FG, Crist TO, Fuller RJ, Sirami C, Siriwardena GM, Martin J-L (2011) Functional landscape heterogeneity and animal biodiversity in agricultural landscapes. Ecol Lett 14:101-112

67. Karp A, Richter GM (2011) Meeting the challenge of food and energy security. J Exp Bot 62:3263-3271

68. Wallander S, Claassen R, Nickerson C (2011) The ethanol decade: an expansion of U.S. corn production, 2000-09. ElB-79, U.S. Department of Agriculture, Economic Research Service.

69. Westphal C, Steffan-Dewenter I, Tscharntke T (2003) Mass flowering crops enhance pollinator densities at a landscape scale. Ecology Letter 6:961-965

70. Vollrath B, Kuhn W (2010) Wildpflanzen für Biogas - Die Zukunft? Veitshöchheimer Berichte 141:33-39

71. Gansberger M, Montgomery LFR, Liebhard P (2015) Botanical characteristics, crop management and potential of Silphium perfoliatum $\mathrm{L}$. as a renewable resource for biogas production: a review. Ind Crop Prod 63:362-372

72. Stanley DA, Stout JC (2013) Quantifying the impacts of bioenergy crops on pollinating insect abundance and diversity: a field-scale evaluation reveals taxon-specific responses. J Appl Ecol 50:335-344 
73. Schorpp Q, Schrader S (2016) Earthworm functional groups respond to the perennial energy cropping system of the cup plant (Silphium perfoliatum L.). Biomass Bioenerg 87:61-68

74. Tsonkova P, Böhm C, Quinkenstein A, Freese D (2012) Ecological benefits provided by alley cropping systems for production of woody biomass in the temperate region: a review. Agrofor Syst 85:133-152

75. Jose S (2009) Agroforestry for ecosystem services and environmental benefits: an overview. Agroforest Syst 76:1-10

76. Smith J, Pearce BD, Wolfe MS (2013) Reconciling productivity with protection of the environment: is temperate agroforestry the answer? Renew Agr Food Syst 28:80-92

77. Haaland C, Gyllin M (2010) Butterflies and bumblebees in greenways and sown wildflower strips in southern Sweden. J Insect Conserv 14:125-132

78. Tschumi M, Albrecht M, Entling MH, Jacot K (2015) High effectiveness of tailored flower strips in reducing pests and crop plant damage. Proc R Soc B 282:20151369

79. FNR (2011) Standortangepasste Anbausysteme für Energiepflanzen, 4th edn. Fachagentur für nachwachsende Rohstoffe e.V, Gültzow

80. Schittenhelm S, Schroetter S (2014) Comparison of drought tolerance of maize, sweet sorghum and sorghum-sudangrass hybrids. Journal of Agronomy and Crop Science 200:46-53

81. Schümann K, Engel J, Frank K, Huth A, Luick R, Wagener F (2010) Naturschutzstandards für den Biomasseanbau. Ergebnisse des gleichnamigen F+E-Vorhabens (FKZ 3507 82-150). Bundesamt für Naturschutz (BfN), Bonn-Bad Godesberg

82. Lovett AA, Sünnenberg GM, Richter GM, Dailey AG, Riche AB, Karp A (2009) Land use implications of increased biomass production identified by GIS-based suitability and yield mapping for Miscanthus in England. Bioenerg Res 2:17-28

83. Fiorese G, Guariso G (2010) A GIS-based approach to evaluate biomass potential from energy crops at regional scale. Environ Modell Softw 25:702-711

84. Dale VH, Kline KL, Buford MA, Volk TA, Smith CT, Stupak I (2016) Incorporating bioenergy into sustainable landscape designs. Renew Sust Energ Rev 56:158-1171

85. Ruskule A, Nikodemus O, Kasparinska Z, Kasparinskis R, Brumelis G (2012) Patterns of afforestation on abandoned agriculture land in Latvia. Agroforest Syst 85:215-23

86. Sanderson MA, Adler PR (2008) Perennial forages as second generation bioenergy crops. Int J Mol Sci 9:768-788

87. Smyth BM, Murphy JD, O'Brien CM (2009) What is the energy balance of grass biomethane in Ireland and other temperate northern European climates? Renew Sustain Energy Rev 13:2349-2360

88. Vickery JA, Tallowin JR, Feber RE, Asteraki EJ, Atkinson PW, Fuller RJ, Brown VK (2001) The management of lowland neutral grasslands in Britain: effects of agricultural practices on birds and their food resources. J Appl Ecol 38:647-664

89. Power EF, Stout JC (2011) Organic dairy farming: impacts on insect-flower interaction networks and pollination. J Appl Ecol 48:561-569

90. Gelfand I, Sahajpal R, Zhang X, Izaurralde RC, Gross KL, Robertson GP (2013) Sustainable bioenergy production from marginal lands in the US Midwest. Nature 493:514-517

91. Glemnitz M, Platen R, Krechel R, Konrad J, Wagener F (2013) Can shortrotation coppice strips compensate structural deficits in agrarian landscapes? Aspect Appl Biol 118:153-162

92. Giraldo C, Escobar F, Chará J, Calle Z (2010) The adoption of silvopastoral systems promotes the recovery of ecological processes regulated by dung beetles in the Colombian Andes. Insect Conserv Divers 4:115-122

93. Rivera LF, Armbrecht I, Calle Z (2013) Silvopastoral systems and ant diversity conservation in a cattle-dominated landscape of the Colombian Andes. Agric Ecosyst Environ 181:188-194

94. Wezel A, Casagrande M, Celette F, Vian J-F, Ferrer A, Peigné J (2014) Agroecological practices for sustainable agriculture. A review. Agron Sustain Dev 34:1-20

95. Lupp G, Steinhäußer R, Starick A, Gies M, Bastian O, Albrecht J (2014) Forcing Germany's renewable energy targets by increased energy crop production: A challenge for regulation to secure sustainable land use practices. Land Use Policy 36:296-306

\section{Submit your manuscript to a SpringerOpen ${ }^{\circ}$ journal and benefit from:}

- Convenient online submission

- Rigorous peer review

- Immediate publication on acceptance

- Open access: articles freely available online

- High visibility within the field

- Retaining the copyright to your article

Submit your next manuscript at $\gg$ springeropen.com 